Jurnal Darussalam; Jurnal Pendidikan, Komunikasi dan Pemikiran Hukum Islam

Vol. XI, No 2:479-500. April 2020. ISSN: 1978-4767 (Cetak), ISSN: 2549-4171(Online)

Terakreditasi Nasional. SK. No.36/E/KPT/2019

\title{
PEMENUHAN HAK ANAK PASCA PERCERAIAN ORANG TUA
}

\author{
Nyoto, Budi Kisworo, Rifanto bin Ridwan, Hasep Saputra \\ Program Studi Ahwalu Syahksiyah, Institut Agama Islam Negeri Curup \\ Email: nyotoiaincurup@gmail.com ${ }^{1}$, \\ budikisworo@iaincurup.ac.id², rifanto@iaincurup.ac.id ${ }^{3}$, \\ hasepsaputra@iaincurup.ac.id ${ }^{4}$
}

\begin{abstract}
This study aims to determine the fulfillment of children's rights after parental divorce in Rejang Lebong Regency. Knowing the obstacles experienced by parents so that they cannot fulfill their children's rights after divorce. This is to find out the implications of not fulfilling children's rights after parents' divorce on children's lives. This study uses a qualitative method to describe the fulfillment of children's rights after their parents' divorce. Barriers experienced by parents in fulfilling children's rights. As well as the implications of not fulfilling the rights of children. The results show that the responsibility of parents is not only concerned with the child's growth and development but also with the physical health of the child itself, the obligations and responsibilities of parents towards the child, at this time, that divorced parents have the responsibility to regulate the obligations towards the child. post-divorce child. Starting from the arrangement of child custody, child support so that no problems arise after the divorce between parents
\end{abstract}

\section{Keywords: Fulfillment of Children's Rights, Parents Divorce}

\begin{abstract}
Abstrak
Penelitian ini bertujuan untuk mengetahui pemenuhan hak-hak anak pasca perceraian orang tua di Kabupaten Rejang Lebong. Mengetahui hambatan yang dialami orang tua sehingga tidak dapat memenuhi hak-hak anak pasca perceraian. Untuk mengetahui implikasi tidak terpenuhinya hak-hak anak pasca perceraian orang tua terhadap kehidupan anak. Penelitian ini menggunakan metode kualitatif untuk mendeskripsikan pemenuhan hak-hak anak pasca perceraian orang tua. Hambatan-hambatan yang dialami orang tua dalam memenuhi hak-hak anak. Serta implikasi tidak terpenuhinya hak-hak terhadap kehidupan anak. Hasil penelitian menunjukkan bahwa tanggung awab orang tua bukan hanya memperhatikan tumbuh kembang anak saja tetapi juga dalam kesehatan fisik anak itu sendiri, kewajiban dan tanggung jawab orang tua terhadap anak, pada saat ini, bahwa orang tua yang sudah bercerai memiliki tanggung jawab untuk pengaturan kewajiban terhadap anak pasca perceraian. Mulai dari pengaturan hak asuh anak, nafkah anak sehingga tidak muncul masalah setelah terjadinya perceraian antara orang tua.
\end{abstract}

\section{Kata Kunci: Pemenuhan Hak Anak, Perceraian Orang Tua}


A. Pendahuluan

Permasalahan yang terjadi baik di desa, Kelurahan maupun Provinsi adalah terjadinya perceraian. Terjadinya perceraian tanpa didasari tidak hanya akan menghancurkan fungsi yang harus dijalani oleh sebuah lembaga keluarga, tetapi juga melenyapnya fondasi jaringan sosial mendasar yang ada dalam sebuah masyarakat (Ekaningsih, 2016:97). Perceraian juga menyisakan permasalahan terutama persoalan pemenuhan hak-hak anak yang mencakupi seluruh hak yang melekat pada anak yaitu hak memperoleh pendidikan, kesehatan, biaya pemeliharaan dan lain sebagainya. Persoalan pemenuhan hak-hak anak menunjukkan bahwa masih terdapat sebagian besar para orang tua belum memenuhi hak-hak anak pasca perceraiannya.

Pemahaman para orang tua di Kapubaten Rejang Lebong selama ini masih minim tentang pemenuhan hak-hak anak pasca perceraian dan hak-hak anak apa saja yang semestinya dipenuhi Akibat perceraian para orang tua di Kabupaten Rejang Lebong terkadang hak-hak anak ada yang dikesampingkan kurang terurus dengan serius, terutama yang berkaitan dengan hak-hak pokok anak yaitu biaya pemeliharaan, pendidikan, tempat tinggal dan fasilitas-fasilitas penunjang lainnya. Terlebih lagi ketika orang tuanya masing-masing sudah memiliki keluarga baru sehingga memungkinkan berkurangnya waktu untuk mengurusi hak-hak anaknya. Meskipun orang tua sudah tidak lagi dalam satu keluarga, tetapi persoalan pemenuhan hak-hak anak tetap menjadi tanggung jawab orang tua dan tidak boleh dialihkan kepada orang lain selain kedua orang tuanya. Menimbulkan persoalan berupa kurang terpenuhinya hak-hak anak pasca perceraiannya.

Penelitian Pemenuhan hak-hak anak pasca perceraian orang tua ini dilakukan di Kabupaten Rejang Lebong ini, diharapkan akan memberikan sumbangan ilmiah akademis kepada semua pihak, agar selalu memberikan pemahaman tentang hak dan kewajiban orang tua pada anak pasca bercerai. Kemudian menjadi rujukan baik secara konsep khazanah keilmuan, maupun secara praktis implementatif, sehingga bisa mencapai kemajuan sehingga anak tidak akan menjadi terlantar dan keberhasilan dalam pengembangan masyarakat yang madani. 


\section{B. Landasan Teori}

\section{Perlindungan Anak}

Menurut Nuruddin (2004) Perlakuan orang tua terhadap anaknya mengenai pemenuhan hak-hak anak di Kapubaten Rejang Lebong selama ini sedikit bertolak belakang dengan ketentuan pemenuhan hak-hak anak yang sesungguhnya. Pada pasal 41 Undang-undang No 1 tahun 1974 tentang Perkawinan yang menegaskan pada dasarnya baik ibu atau bapak tetap berkewajiban memelihara dan mendidik anakanaknya, semata-mata berdasarkan kepentingan anak (poin a). Biaya pemeliharaan dan pendidikan anak- anak menjadi tanggung jawab pihak bapak, kecuali dalam kenyataannya bapak dalam keadaan tidak mampu sehingga tidak dapat melakukan kewajiban tersebut (poin b).

Sementara berdasarkan data dari Lembaga bantuan Hukum Mawar Saron (2015) menyangkut kewajiban orang tua terhadap anak dimuat di dalam Bab X mulai pasal 45 ayat (1) menyatakan. Kedua orang tua wajib memelihara dan mendidik anak-anak mereka sebaik-baiknya. Bahwa meskipun suatu perkawinan sudah putus mengakibatkan hubungan antara orang tua (suami dan isteri yang telah bercerai) dan anak-anak yang lahir dari perkawinan tersebut menjadi putus. Sebab dengan tegas diatur bahwa suami dan istri yang telah bercerai tetap mempunyai kewajiban sebagai orang tua yaitu untuk memelihara dan mendidik anak-anaknya, termasuk dalam hal pembiayaan yang timbul dari pemeliharaan dan pendidikan dari anak tersebut.

Petentuan di atas juga menegaskan bahwa Negara melalui UU Perkawinan tersebut telah memberikan perlindungan hukum bagi kepentingan anak-anak yang perkawinan orang tuanya putus karena perceraian. Secara sosiologis dalam masyarakat seringkali dijumpai istilah "bekas suami" atau "bekas isteri", namun tidak pernah sama sekali dijumpai adanya istilah "bekas bapak", "bekas ibu" atau "bekas anak" karena hubungan darah dari orang tua dan anak tidak pernah dapat dipisahkan oleh apapun juga. Meskipun demikian suatu perceraian selain mempunyai akibat secara hukum juga mempunyai akibat secara sosiologis dan psikologis bagi pribadi 
anak tersebut, untuk itu diperlukan pertimbangan yang matang dan bijaksana sebelum memutuskan untuk mengakhiri perkawinan.

Pola pemenuhan hak-hak anak di Kapubaten Rejang Lebong selama ini, ketika perceraian terjadi kebiasaan masyarakat sesekali anak diberikan bekal atau berupa uang cukup beberapa kali saja dan besarannya tergantung kemampuan ayahnya. Bahkan ada yang memberikan dengan jumlah yang cukup besar akan tetapi cukup hanya sekali pada awalnya saja dan selanjutnya tidak rutin diberikan, besarannya juga yang meninggalkan anak-anaknya begitu saja ke luar negeri dengan tanpa karena perceraian, tidaklah ada meninggalkan biaya hidup atau nafkah. Sementara jika kedua orang tuanya sama-sama mencari nafkah ke luar negeri atau masingmasing sudah berkeluarga maka anak seringkali dititipkan kepada keluarga terdekat yaitu kakek atau nenek dari orang tua ayah atau ibunya.

Mengenai pendidikan anak, biasanya orang tua menyekolahkan anak dari Sekolah Dasar jika kemampuannya mencukupi bahkan ada sebagian kecil yang sampai mengantarkan anak-anaknya ke jenjang Perguruan Tinggi. Mengenai hak- hak anak lainnya tidak begitu dipahami dan dimengerti hak-hak apa saja yang harus dipenuhi. Mereka berpendapat bahwa jika biaya sehari-hari dan dapat disekolahkan maka itulah yang dimaksud dengan pemenuhan hak-hak anak, karena hanya hak-hak itu saja itu saja yang dibutuhkan anak. Dalam hal terjadinya perceraian orang tua anak tersebut, KHI mengaturnya secara rinci dalam pasal 105 pada poin (a) yaitu pemeliharaan anak yang belum mumayyiz atau belum berumur 12 tahun adalah hak ibunya. Sementara pada poin (c) menyebutkan bahwa biaya pemeliharaan ditanggung oleh ayahnya (Hifni, 2017).

Jika melihat ketentuan pasal di atas maka yang bertanggung penuh ketika seorang belum berusia 12 tahun adalah hak melekat pada ibunya. Sementara dalam konteks biaya pemeliharaan sepenuhnya ditanggung oleh ayahnya. Dengan demikian antara ayah dan ibu memiliki porsi atau bagian yang sama dalam memelihara anaknya, ibu berkewajiban memelihara penuh ketika anak belum mumayyiz dan ayah memenuhi biaya pemeliharaannya. Adapun pelaksanaan dari pasal $105 \mathrm{KHI}$, ibu mendapat prioritas utama untuk mengasuhnya selama anak tersebut belum mumayyiz. 
Dan apabila si anak sudah mumayyiz maka anak disuruh memilih, kepada siapa diantara ayah dan ibunya dia akan ikut. KHI juga melakukan antisipasi jika kemungkinan seorang bayi disapihkan kepada perempuan yang bukan ibunya. Hal ini dijelaskan dalam pasal 104 ayat (1) yang berbunyi "Semua biaya penyusuan dipertanggungjawabkan kepada ayahnya. Apabila ayahnya telah meninggal dunia, maka biaya penyapihan dibebankan kepada orang yang berkewajiban memberi nafkah kepada ayahnya atau walinya".

Dalam hal kesejahteraan anak-anak yang orang tuanya bercerai, yang terganggu bukan saja kesejahteraan fisik atau materi, namun juga kesejahteraan emosional atau rohani. Anak-anak yang dibesarkan oleh orang tua tunggal (biasanya ibu) jelas tidak dapat menikmati proses perkembangan mental seperti teman-temannya yang orang tuanya lengkap. Anak-anak umumnya ikut tinggal bersama ibunya. Ketika ibunya menikah lagi, anak-anak tidak diperkenankan tinggal bersama ayah tirinya. Mereka akan tetap tinggal dengan keluarga dari pihak ibu. Keterbatasan ekonomi keluarga seringkali memaksa anak untuk berpindah tempat tinggal dari satu kerabat ke kerabat lainnya yang bersedia menampung mereka. Keadaan tersebut dapat memunculkan dampak buruk dalam kehidupan anak, misalnya dalam hal pendidikan, kesehatan, kegagalan penyesuaian diri dengan lingkungan yang selalu berganti-ganti, gangguan perkembagan mental, menurunnya rasa percaya diri, dan sikap tertutup. Sangat ironis memang jika setiap orang tua belum tentu mampu memahami dan memposisikan secara keselurahan atas hak-hak setiap anaknya (Duriyati, 2009).

Berdasarkan Undang-undang RI No. 23 tahun 2002 tentang Perlindungan Anak pasal 1 ditegaskan bahwa anak adalah seseorang yang belum berusia 18 tahun (delapan belas) tahun, termasuk anak yang masih dalam kandungan. Ketentuan dalam Undang-undang di atas menerangkan bahwa anak yang masih dalam kandungan pun dikategorikan anak sampai dengan anak berusia 18 tahun. Sementara pengertian anak dalam konteks hukum perdata erat kaitannya dengan pengertian mengenai kedewasaan. Hukum Indonesia mengenai anak masih digolongkan sebagai anak terdapat perbedaan penentuan. 
Menurut Setyowati (1990) ketentuan hukum terdapat perbedaan tolok ukur dimaksud antara lain Kitab undang-undang hukum perdata (BW) Pasal 330 yang berbunyi: Ayat 1:

Memuat batas antara belum dewasa (Minderjerigheid) dengan telah dewasa Meerderjarigheid) yaitu 21 tahun kecuali: Anak itu sudah kawin sebelum berumur 21 tahun Pendewasaan (venia aetetis pasal 419) Undang-undang No. 1 tahun 1974 tentang Perkawinan Pasal 47 ayat 1 menyatakan bahwa anak yang belum mencapai umur 18 tahun atau belum pernah melakukan pernikahan ada di bawah kekuasaan orang tuanya selama mereka tidak dicabut kekuasaan orang tuanya. Pasal 50 ayat 1 berbunyi anak yang belum mencapai umur 18 tahun atau belum pernah kawin, yang tidak berada di bawah kekuasaan orang tua, berada di bawah kekuasaan wali.

Dari pasal-pasal dalam Undang-undang No. 1 Tahun 1974 tentang Perkawinan tersebut di muka dapat disimpulkan bahwa dalam Undang-undang tersebut menentukan batas belum dewasa atau sudah dewasa adalah 16 tahun ada 19 tahun. Hukum kebiasaan (hukum adat dan hukum Islam). Menurut hukum adat tidak ada ketentuan yang pasti kapan seseorang dapat dianggap dewasa dan wewenang bertindak.

\section{Hak-Hak Anak Perpektif Hak Asasi Manusia (HAM)}

Undang-undang No. 26 Tahun 2000 tentang Pengadilan Hak Asasi Manusia. Ketetapan MPR RI No. X/MPR/2001 tentang Laporan Pelaksanaan Putusan MPR RI oleh Lembaga Tinggi Negara pada Sidang Tahunan MPR RI Tahun 2001. Undangundang No. 23 Tahun 2002 tentang Perlindungan Anak. Keputusan Presiden RI No. 59 Tahun 2002 tentang Rencana Aksi Nasional Penghapusan Bentuk-bentuk Pekerjaan Terburuk untuk Anak. Keputusan Presiden RI No. 87 Tahun 2002 tentang Rencana Aksi Nasional Penghapusan Eksploitasi Seksual Komersial Anak. Undangundang No. 21 Tahun 2007 Tentang Pemberantasan Tindak Pidana Perdagangan Orang.

Sementara dalam hal perlindungan anak adalah disebutkan segala kegiatan untuk menjamin dan melindungi anak dan hak-haknya agar dapat hidup, tumbuh, kemanusiaan, serta mendapat perlindungan dari kekerasan dan diskriminasi. Dalam pasal 2 Undang-undang No. 4 tahun 1979 tentang Kesejahteraan Anak 
merumuskan hak-hak anak sebagai berikut: Anak berhak atas kesejahteraan, perawatan, asuhan dan bimbingan berdasarkan kasih sayang baik dalam keluarganya maupun di dalam asuhan khusus untuk tumbuh dan berkembang dengan wajar (Yuliana, 2017).

Anak berhak atas pelayanan untuk mengembangkan kemampuan dan kehidupan sosialnya, sesuai dengan kepribadian bangsa dan untuk menjadi warga negara yang baik dan berguna. Anak berhak atas perlindungan terhadap lingkungan hidup yang dapat membahayakan atau menghambat pertumbuhan dan perkembangan dengan wajar.

Sementara dalam Undang-undang No. 23 tahun 2002 tentang Perlindungan Anak yang mengatur hak-hak anak dan dikemukakan dengan tegas dalam pasal 4 sampai dengan pasal 18 menyebutkan: Pasal 4 mengatur tentang hak untuk dapat hidup, tumbuh, berkembang, dan berpartisipasi secara wajar; Pasal 5 mengatur tentang hak memperoleh nama sebagai suatu identitas diri; Pasal 6 hak untuk beribadah; Pasal 7 ayat (1) dan pasal 14 mengatur tentang hak memperoleh asuhan; Pasal 8 mengatur tentang hak memperoleh pelayanan kesehatan dan jaminan sosial; Pasal 9 ayat (1) mengatur tentang hak memperoleh pendidikan; Pasal 11 mengatur tentang hak untuk berekreasi dan berkreasi; Pasal 12 dan Pasal 9 ayat (2) mengatur tentang hak memperoleh pelayanan khusus; Pasal 13, 15, 16, 17 ayat (1) dan (2) serta pasal 18 mengatur tentang hak memperoleh perlindungan kekerasan, penganiayaan dan hukum;

Hak-hak anak yang disebutkan di atas pada hakikatnya adalah merupakan hak yang sejatinya diberikan oleh orang tua pasca perceraiannya dan segala aspek tersebut merupakan bagian dari kegiatan pembangunan khusus di dalam memajukan kehidupan berbangsa dan bernegara. Hak-hak anak tersebut diperjelas dalam BAB III Undang-undang No. 23 tahun 2002 tentang Perlindungan Anak sebagai berikut: Pasal 4 menyatakan: Setiap anak berhak untuk dapat hidup, tumbuh berkembang, dan berpartisipasi secara wajar sesuai dengan harkat dan martabat memanusiakan manusia, serta mendapat perlindungan dari kekerasan dan diskriminasi. 
Setyowati (1990) menjelaskan bahwa ketentuan hak-hak Anak Perspektif Hukum Islam Hak-hak dalam perspektif Islam terdapat dalam dua konteks kajian pembahasan yaitu kompilasi hukum Islam dan fikih. Masing-masing menjelaskan tentang pemeliharaan dan hak-hak anak yang dipenuhi orang tua. Hak anak menurut Kompilasi Hukum Islam (KHI) Pasal yang secara ekspilisit mengatur masalah kewajiban pemeliharaan anak dan harta jika terjadi perceraian, ketentuan tersebut terdapat di dalam pasal 105 dan 106.

Dalam hal terjadinya perceraian: a) Pemeliharaan anak yang belum mumayyiz atau belum berumur 12 tahun (dua belas) adalah hak ibunya; b) Pemeliharaan anak yang sudah mumayyiz diserahkan kepada anak untuk memilih di antara ayah atau ibunya sebagai pemegang hak pemeliharaannya; c) Biaya pemeliharaan anak di tanggung oleh ayah.

Berdasarkan ketiga ketentuan pasal tersebut di atas semua menitikberatkan kepada kewajiban orang tua terutama ketika anak yang belum berumur 12 tahun, sementara dalam hal pemeliharaan anak yang sudah mumayyiz sepenuhnya diserahkan kepada anak atau hak anak untuk memilih di antara keduanya ayah atau ibunya untuk memegang hak pemeliharaan. dan pada ketentuan lainnya biaya pemeliharaan anak sepenuhnya merupakan tanggung jawab yang tanggung ayah, ditegaskan pada pasal 106 ayat (1) Orang tua berkewajiban merawat dan mengembangkan harta anaknya yang belum dewasa atau di bawah pengampuan, dan tidak diperbolehkan memindahkan atau menggadaikannya kecuali karena keperluan yang mendesak jika kepentingan dan kemaslahatan anak itu menghendaki atau suatu kenyataan yang tidak dapat dihindarkan. Dan ayat (2) menegaskan: Orang tua bertanggung jawab atas kerugian yang ditimbulkan karena kesalahan dan kelalaian. Pada ayat (2) ini memberikan ketegasan bahwa jika terjadi kerugian atas harta anak tersebut yang disebabkan karena faktor kelalaian dan kesalahan, maka semuanya menjadi tanggung jawab orang tua, baik ayah atau ibunya.

Mengenai ketentuan hak anak dalam mendapatkan biaya penyusuan, dijelaskan dalam pasal 104 ayat (1) Semua biaya penyusuan anak dipertanggungjawabkan kepada ayahnya. Dan ketegasaan batas waktu menyusukan anak, dijelaskan pada ayat 
(2) Penyusuan dilakukan untuk paling lama dua tahun dan dapat dilakukan penyapihan dalam masa kurang dua tahun dengan persetujuan ayah dan ibunya.

Selanjutnya, tanggung jawab pemeliharaan berupa pengawasan dan pelayanan serta pencukupan nafkah anak tersebut bersifat kontinu sampai anak tersebut mencapai batas umur yang legal sebagai orang dewasa yang telah mampu berdiri sendiri. Disamping itu juga, pendidikan dalam hal ini dimaksudkan adalah kewajiban orang tua untuk memberikan pendidikan dan pengajaran yang memungkinkan anak menjadi manusia yang mempunyai kemampuan dan dedikasi hidup yang dibekali dengan kemampuan dan kecakapan sesuai dengan pembawaan bakat anak tersebut.

Proses pemeliharaan anak dan pendidikannya akan dapat berjalan dengan baik, jika kedua orang tua saling membantu. Tentu saja ini dapat dilakukan dengan baik jika keluarga tersebut benar-benar keluarga yang sakinah dan mawaddah. Permasalahannya sekarang adalah bagaimana pemeliharaan anak jika terjadi perceraian. Bila terjadi pemutusan perkawinan karena perceraian, baik ibu.

Sebagaimana yang sudah dikemukakan di dalam hukum Islam yang dibebani tugas kewajiban memelihara dan mendidik anak adalah bapak, sedangkan ibu bersifat membantu. Ibu hanya berkewajiban menyusui anak dan merawatnya. Sesungguhnya dalam hukum islam sifat hubungan hukum antara orang tua dan anak dapat dilihat dari segi materialnya, yaitu memberi nafkah, menyusukan (irdla') dan mengasuh (hadlanah), dan dari segi immaterial yaitu curahan cinta kasih, penjagaan dan perlindungan serta pendidikan rohani dan lain- lain (Hadikususma, 2003).

Pembentukan kepribadian dari seorang manusia, agar mereka kelak memiliki kekuatan dan kemampuan serta mampu berdiri tegar dalam meniti kehidupan. Hal ini terkandung dalam kewajiban orang tua setelah melahirkan dan menyusui seperti yang telah dijelaskan sebelumnya adalah membesarkan anak, yaitu dengan mendidiknya sesuai dengan dengan syari'at Islam. Untuk membesarkan anak, Allah memberi kita rizki agar dapat menyekolahkannya serta mendidiknya dengan baik. Di dalam surah Al-Isra: 70 Allah SWT berfirman:

Artinya: Dan sesungguhnya telah Kami muliakan anak-anak adam, Kami angkut mereka di daratan dan dilautan, Kami beri mereka rezki dari yang baik- 
baik dan Kami lebihkan mereka dengan kelebihan yang sempurna atas kebanyakan makhluk yang telah Kami ciptakan.

\section{Metode Penelitian}

Pendekatan yang digunakan dalam penelitian ini adalah pendekatan kualitatif, mengingat data-data yang diperoleh hanya bersifat gambaran keadaan yang dituangkan dalam kata-kata, bukan dalam bentuk angka seperti dalam penelitian kuantitatif. Dalam hal ini peneliti mengkaji tentang bagaimana mendalami fokus yang diteliti serta mengungkapkan secara mendetail (Sucia, 2017).

Penelitian kualitatif adalah mengamati orang dalam lingkungan hidupnya, berinteraksi dengan mereka, serta berusaha memahami bahasa dan tafsiran mereka tentang dunia sekitar. Oleh karena itu, penelitian kualitatif yang mengamati secara langsung orang dalam lingkungan sekitar, menyesuaikan diri dengan obyek yang diteliti serta memahami bahasa dan budaya sekitar mereka sehingga hasil yang didapatkan merupakan realitas keadaan masyarakat (Mansari, \& Maulana, 2018).

Pendekatan yang digunakan dalam penelitian ini adalah penelitian kualitatif. Pendekatan kualitatif ini bertujuan untuk mendapatkan data-data dari gejala sosial ataupun fenomena-fenomena tentang pemenuhan hak-hak anak pasca perceraian orang tua yang terjadi di Kapubaten Rejang Lebong. Fenomena yang dimaksud adalah tentang pemenuhan hak-hak anak yang terjadi di Kapubaten Rejang Lebong. Penelitian ini mendeskripsikan pemenuhan hak-hak anak pasca perceraian orang di Kapubaten Rejang Lebong. Hambatan-hambatan yang dialami orang tua dalam

memenuhi hak-hak anak. Serta implikasi tidak terpenuhinya hak-hak terhadap kehidupan anak.

\section{Hasil}

\section{Pemenuhan Hak-Hak Anak Pasca Perceraian Orang Tua di Kapubaten Rejang}

\section{Lebong}

Berbicara tentang hak anak yang diperoleh pasca perceraian adalah sebuah kenyataan yang memunculkan banyak polemik. Di satu pihak anak membutuhkan perhatian dan penghidupan dari orang tua, namun di sisi lain kenyataan yang 
mengharuskan ia berjuang dalam hidup hanya dengan single parentsebagai konsekuensi dari perceraian yang terjadi dalam kehidupan orangtuanya. Kenyataan ini tentu saja memiliki dampak positif dan negatifnya.

Perceraian menjadi permasalahan dalam pemenuhan hak anak, seperti yang telah di jelaskan di atas. Hal tersebut tentu berkaitan dengan persoalan ekonomi dan kematangan emosional dalam menghadapi permasalahan hidup,. Disisi lain juga dipengaruhi oleh umur.

Kebiasaan masyarakat dalam memenuhi hak-hak anaknya tidak sesuai dengan hukum, yang menjadi pedoman orang tua adalah kebiasaan, bukan berlandaskan hukum. Kemudian, bersama siapapun anak tinggal maka dialah yang mengurus. Sementara hak-hak anak yang biasa diberikan adalah biaya hidup, biaya sekolah dan biaya yang lainnya. Sulit bagi orang tua untuk menerima peraturan hukum dan pemerintah, persoalannya adalah karena faktor kebiasaan sebagai pedoman. Bagaimanapun bentuk kebiasaan masyarakat maka itulah yang dipedomani. Selain itu juga banyak orang tua merasa gengsi jika dikatakan tidak mampu mengurus anaknya. Berbagai upaya dilakukan agar tidak dikatakan lalai.

\section{Hambatan-hambatan orang tua dalam memenuhi hak-hak anak pasca perceraian di Kabupaten Rejang Lebong}

Kapubaten Rejang Lebong memiliki angka kasus perceraian banyak terjadi dari tahun ke tahun dalam angka yang tidak terlalu tinggi. Berdasarkan data penelitian yang diperoleh penulis tentang kasus perceraian dan putusan pengadilan perihal perceraian, diketahui bahwa di antara beberapa kasus perceraian yang terjadi di Kapubaten Rejang Lebong, kasus perceraian dengan telah adanya anak.

Jika memperhatikan penuturan responden dalam penelitian ini menunjukkan bahwa perceraian disebabkan oleh himpitan faktor ekonomi. Mereka kurang tabah menghadapi masalah ekonomi yang sebetulnya tidak perlu sampai bercerai. Orang tua yang melahirkan berkewajiban memenuhi hak-hak mereka yang berhubungan dengan idangnya sebagai orang tua, karena ketentuan undang-undang ini menjelaskan bahwa pemenuhan hak anak dimulai sejak dalam kandungan, yakni hak 
untuk hidup, hak untuk dipelihara, tidak dijauhkan dari orang tua, dan lain sebagainya.

Konvensi hak anak yang mengatur hak-hak anak secara lebih rinci, konvensi ini merumuskan prinip-prinsip hak anak yang ditujukan untuk melindungi hak anak. Tidak seorang anak pun dapat dirampas kemerdekaannya secara sewenang-wenang, menjadi sasaran penyiksaan atau perlakuan/penghukuman lain yang kejam, tidak manusiawi atau merendahkan martabat, hukuman mati, atau hukuman seumur hidup. Apabila anak yang ditelantarkan, maupun tidak diberikan nafkah dari orang dewasa dalam artian di sini adalah orang tua, karna hak anak tersebut juga harus diperhatikan oleh orang tua maupun walinya. Di dalam KUH Perdata secara jelas dapat di lihat mengenai hak anak, walaupun tidak secara rinci dijelaskan mengenai hak-hak anak di dalam KUH Perdata. Tetapi bisa kita lihat dalam Pasal 2 buku satu tentang orang, yang berbunyi : "Anak yang ada dalam kandungan seorang perempuan dianggap telah lahir, setiap kali kepentingan si anak menghendakinya. Bila telah mati sewaktu dilahirkan, dia dianggap tidak pernah ada". Di sini dijelaskan bahwa anak tersebut sejak dalam kandungan juga mempunyai hak dan kepentingan yang diperhitungkan dan dilindungi oleh Negara dan diatur di dalam undang-undang itu sendiri.

Instrument hukum tersebut menjadi landasan untuk melindungi hak anak dan kepentingan hidup anak pasca perceraian. Salah satu penjabaran dari penjabaran dari perlindungan hak-hak anak yaitu setiap anak berhak untuk dapat hidup, tumbuh, berkembang, dan berpartisipasi secara wajar sesuai dengan harkat dan martabat kemanusiaan, serta mendapat perlindungan dari kekerasaan dan diskriminasi oleh karena itu perlindungan Undang-undang No. 23 Tahun 2002 Tentang Perlindungan Anak. Dalam aplikasi yang diatur dalam Undang- Undang Dasar 1945 Undangundang No. 23 Tahun 2002 tentang Perlindungan Anak, dan Undang-undang No. 4 Tahun 1979 Tentang Kesejahteraan Anak.

Semua diaplikasikan ke masyarakat Republik Indonesia yang terlebih khusus ditinjau dari masyarakat Sulawesi Utara belum sepenuhnya melaksanakan amanah undang-undang yang mengatur tentang anak yang berlaku di Republik Indonesia dengan baik. Banyaknya hak-hak anak yang belum terpenuhi oleh orang tua dari sang 
anak tersebut. Dalam peraturan perundang-undangan yang berlaku di Indonesia maupun konvensi tentang Hak-Hak Anak (convention on the Rights of the Child), Resolusi No. 109 Tahun 1990, dan perundang-undangan lain yang berlaku di Republik Indonesia. Dalam perkara pasca perceraian banyak juga terjadi pengabaian hak anak yang dlakukan oleh orang tua anak itu sendiri, itu sebabnya mengakibatkan mental maupun psikis anak yang mengalami pasca perceraian orang tuanya menjadi terganggu. Karena banyak anak-anak yang mengalami trauma akibat orang tua mereka bercerai dan juga banyak anak yang hak anak mereka terabaikan oleh orang tua yang karena orang tua mereka tidak lagi bersama/bersatu (bercerai).

Implikasi tidak terpenuhinya hak-hak anak pasca perceraian orang tua terhadap kehidupan anak di Kabupaten Rejang Lebong

Hak dan kewajiban orang tua terhadap anak dilihat dari segi Undang-Undang No. 1 Tahun 1974 tentang Perkawinan. Orang tua juga mempunyai hak dan kewajiban untuk bisa lebih memperhatikan dan menegakkan hak anak yang sering diabaikan oleh orang tua dari anak itu sendiri. Didalam Undang-undang No. 1 Tahun 1974 Tentang Perkawinan itu terdapat dalam beberapa pasal. Dalam Undang-undang No. 1 Tahun 1974 Tentang Perkawinan, yang dimana dikatakan berdasarkan Pasal 45 ayat (2) Undang-undang No. 1 Tahun 1974, orang tua dengan sendirinya menurut hukum berkedudukan dan berkapasitas sebagai wali anak-anak sampai mereka dewasa. Oleh karena itu, orang tua adalah kuasa yang mewakili kepentingan anakanak yang belum dewasa kepada pihak ketiga maupun di depan Pengadilan tanpa memerlukan surat kuasa khusus dari anak tersebut.

Dalam undang-undang yang telah dipaparkan di atas dan sudah dijelaskan bahwa kewajiban dan tanggung jawab orang tua terhadap anak, pada saat ini yang akan dipaparkan bahwa orang tua yang sudah bercerai bagaimana pengaturan kewajiban dan tanggung jawabannya terhadap anak pasca percerian. Mulai dari pengaturan pemeliharaan (hak asuh) anak, nafkah anak yang sering menimbulkan masalah setelah terjadinya perceraian antara orang tua. Dan akan dipaparkan mengenai 2 (dua) hal tersebut, yakni: (a). Pemeliharaan, (b) Nafkah anak pasca terjadinya perceraian orang tuanya. 
Dalam Pasal 41 huruf (b) Undang-undang No. 1 Tahun 1974 tentang Perkawinan disebutkan: "akibat putusnya perkawinan karena perceraian ialah, bapak yang bertanggung jawab atas semua biaya pemeliharaan dan pendidikan yang diperlukan anak itu, bilamana bapak dalam kenyataan tidak dapat memenuhi kewajiban tersebut, pengadilan dapat menetukan bahwa ibu ikut memikul biaya tersebut". Menurut pasal di atas, apabila terjadi percerian suami istri, maka yang wajib memikul nafkah anak-anak mereka adalah bapak, meskipun hak pemeliharaan anak berada dalam di tangan ibunya. Namun bilamana kenyataannya bapak tidak mampu member biaya dan nafkah hidup anak-anak mereka karena keadaan ekonominya yang tidak memungkinkan melaksanakan kewajiban itu, maka pengadilan dapat menentukan ibu ikut bertanggung jawab atas biaya nafkah anakanakny. Dari ketentuan pasal-pasal tersebut dapat diketahui bahwa, meskipun perceraian itu terjadi atas kehendak suami (cerai talak) ataupun atas kehendak istri (cerai gugat), maka masalah nafkah anak telah merupakan kewajiban bapak, sampai si anak dewasa atau telah berumur 18 tahun atau telah kawin.

Kecuali sebagimana yang diatur dalam Pasal 41 huruf (b) Undang-undang No. 1 Tahun 1974 tentang Perkawinan bahwa jika bapak tidak mampu karena keadaan ekonominya yang tidak memungkinkan, maka pengadilan dapat menetukan ibu ikut memikul biaya tersebut. Alasan seorang bapak tidak memberikan nafkah untuk anakanaknya dapat dibedakan kepada tiga kriteria. Pertama, seorang bapak menolak melakukan tanggung jawab (refuse of responsibility) memberikan nafkah untuk anakanaknya. Kasus semacam ini banyak terjadi terutama ketika suami istri yang telah pisah tempat tinggal atau suami yang dengan sengaja meninggalkan istri dan anak-anaknya.Kedua, seorang bapak yang lalai (negligent) menunaikan memberi nafkah untuk anaknya.Ketiga, seorang bapak yang gagal (failure) menunaikan kewajibannya nafkah anak-anaknya. Seorang suami yang gagal menunaikan tanggung jawabnya sebenarnya ia telah berusaha secara maksimal tetapi hasil yang diperoleh tidak sesuai dengan yang diharapkan. 


\section{E. Pembahasan}

\section{Pemenuhan Hak-hak anak pasca perceraian orang tua di Kabupaten Rejang} Lebong

Dalam penelitian ini ditemukan adanya pola kebiasaan orang tua dalam memenuhi hak-hak anak ada sebagian yang secara penuh memenuhi, ada juga yang secara tidak penuh dan bahkan ada yang tidak memenuhinya. Artinya salah satu dari kedua orang tua entah ayah atau ibu yang tidak memenuhi hak-hak anaknya. Menurut pengakuan para orang tua bahwa yang dimaksudkan memenuhi hak-hak anak adalah memberikan segala yang kebutuhananak baik itu makan, minum, sekolah dan biaya sehari-hari, jika hal tersebut sudah diberikan maka itulah yang dimaksud dengan memenuhi hak-hak anak.

Pola kebiasaan orang tua hanya memberikan hak pendidikan, biaya hidup seharihari, termasuk juga makan dan minum serta fasilitas lainnya. Padahal hakikatnya yang sesungguhnya pemenuhan hak-hak anak adalah untuk memberikan jaminan agar anak dapat hidup, tumbuh, berkembang, dan berpartisipasi secara optimal sesuai dengan harkat dan martabat kemanusiaan, serta mendapat perlindungan dari kekerasan dan diskriminasi, demi terwujudnya anak yang berkualitas, berakhlak mulia, dan sejahtera. Hal ini sesuai dengan asas dan tujuan dari undang-undang No. 23 tahun 2002 tentang Perlindungan Anak. Kesemuanya ini adalah cerminan bahwa betapa urgennya pemenuhan hak-hak anak terlebih jika orang tuanya telah bercerai.

Undang-undang perlindungan anak telah mencakup beberapa hak-hak anak di antaranya adalah pasal 4 menyebutkan bahwa setiap anak berhak untuk dapat hidup, tumbuh, berkembang, dan berpartisipasi secara wajar sesuai dengan harkat dan martabat kemanusiaan, serta mendapat perlindungan dari kekerasan (Yustisia, 2010). Hak-hak anak yang dimaksudkan dalam pasal 4 ini menegaskan bahwa anak berhak untuk hidup, berkembang hingga mendapatkan perlindungan hukum dari kekerasan dan diskriminasi.

Pemahaman orang tua di Kabupaten Rejang Lebong dalam pemenuhan hak-hak anak masih sangat minim terbukti dengan pengetahuan hanya sebatas hak anak tentang biaya hidup, sekolah formal dan non formal, makan, minum, ibadah, tempat 
tinggal. Pengakuan sebagian besar orang tua tidak dapat memenuhi hak-hak anaknya adalah karena keterbatasn ekonomi atau biaya hidup sehari-hari. Para orang tua menuturkan bahwa mereka memenuhi hak-hak anak sesuai dengan kemampuan ekonomi yang dimiliki. Dari wawancara yang dilakukan mengenai pemenuhan hakhak anak sedikit ada perbedaan menurut pengakuan para orang tua dan anak-anaknya masing.

Mengenai persoalan pola pengasuhan sendiri apabila anak tinggal bersama ibunya maka ibu yang dominan membiayai segala kebutuhan anak, sebaliknya jika anak tinggal bersama dengan ayahnya maka ayah yang lebih dominan membiayai segala kebutuhannya. Tidak banyak di antara kedua belah untuk saling bekerjasama untuk mengurus anaknya masing-masing. Terkadang yang sering terjadi malah pihak ayah atau ibu saling menangguhkan segala biaya kebutuhan anak. Jika kedua belah pihak antara ayah atau ibu kurang mengurus atau bahkan meninggalkan anaknya maka acapkali anak dititipkan kepada keluarga ayah atau ibu, entah itu kakek nenek atau paman.

Pada hakikatnya selain hak-hak yang telah disebutkan di atas ada hak yang sangat urgen yang harus diberikan para orang tua kepada anaknya yaitu hak memperoleh kasih sayang, karena dengan kasihsayang yang penuh inilah akan menjadi pondasi awal orang tua untuk dapat memenuhi hak-hak anak lainnya. Bagaimana mungkin hak-hak lain akan dapat diberikan jika tidak diberikan kasih sayang yang penuh. Hal ini sesuai dengan amanat undang-undang kesejahteraan anak No. 4 tahun 1979 pasal 2 ayat (1) menyatakan bahwa anak berhak atas kesejahteraan, perawatan, asuhan dan bimbingan berdasarkan kasih sayang yang baik dalam keluarganya maupun di dalam asuhan khusus, untuk tumbuh dan berkembang dengan wajar

\section{Hambatan-hambatan orang tua dalam memenuhi hak-hak anak pasca perceraian di Kabupaten Rejang Lebong}

Dalam memenuhi hak-hak anak tentu ada hambatan atau kendala. Hal ini memang tidak bisa dipungkiri namun bukan berarti menjadikan kewajiban orang tua gugur untuk mengasuh, memelihara, serta melindungiseluruh kepentingan anaknya. 
Di Kabupaten Rejang Lebong sendiri hambatan yang dialami orang tua adalah karena keterbatasan ekonomi, yang dimaksudkan di sini adalah belum mampu secara secukupnya memenuhi kebutuhan anak. Hal ini didasari dari pengakuan sebagian para orang tua bahwa hambatan yang dialami dalam memenuhi hak-hak anaknya adalah karena keterbatasan ekonomi.

Sebagian juga yang mengakui bahwa sebaliknya tidak ada hambatan apapun dalam memenuhi hak-hak anaknya. Sementara menurut para tokoh agama dan tokoh masyarakat bahwa selain ekonomi ada juga karena faktor minimnya pendidikan, faktor kelalaian orang tua serta kurangnya kesadaran.Pendapat tersebut jelas berbeda dengan penuturan para orang tua termasuk juga dengan pengakuan anak-anak yang ditinggal cerai orang tuanya.Jika dimungkinkan adanya hambatan dalam memenuhi hak-hak anak maka hak pengasuhan dapat dialihkan kepada kerabat yang ada.

Apabila ada hambatan memenuhi hak-hak anak dalam hal persoalan keterbatasan ekonomi dan hambatan-hambatan lain atau orang tua dalam keadaan fakir tidak ada alasan apapun yang menjadikan kewajiban orang tua gugur. Akan tetapi kewajibannya tetap melekat harus memberikan segalanya untuk anak demi kelangsungan hidupnya. Menurut pendapat jumhur fukaha, jika ayahnya dalam keadaan fakir, tetapi mampu bekerja dan memang benar-benar telah bekerja, tetapi penghasilannya tidak mencukupi, kewajiban memberi nafkah kepada anak-anaknya itu tetap, tidak menjadi gugur (Basir, 2007).

Sedangkan apabila ibunya berkemampuan, dapat diperintahkan untuk mencukupkan nafkah anak-anaknya yang menjadi kewajiban ayah mereka itu, tetapi dapat diperhitungkan sebagai hutang ayah yang pada saat berkemampuan dapat ditagih untuk mengembalikannya. Jika ibu pun termasuk fakir juga, nafkah anak dimintakan kepada kakek (bapak ayah), dan pada saatnya kakek berhak minta ganti nafkah yang diberikan kepada cucunya itu kepada ayah. Apabila bapak itu tidak ada lagi, nafkah anak itu dibebankan kepada kakek (bapak ayah) sebab kakek berkedudukan sebagai pengganti ayah dalam hal ayah telah tidak ada lagi. Sementara menurut Imam Malik, wajib nafkah itu hanya terbatas pada anak-anak sebab ayat alQur'an dengan tegasmenyebutkan kewajiban ayah untuk memberi nafkah kepada 
anak-anaknya. Dengan demikian, kakek, menurut Imam Malik, tidak dibebani wajib nafkah untuk cucu-cucunya.

Pola pengasuhan yang dilakukan keluarga ayah atau ibu inilah yang acapkali terjadi di Kabupaten Rejang Lebong dengan mengambil peran sebagai orang tua memenuhi segala kebutuhan anakkarena adanya faktor kesengajaan penelantaran yang dilakukan orang tua atau tidak diketahui keberadaannya. Mengenai sanksi bagi orang tua yang terbukti melalaikan kewajibannya, di Kabupaten Rejang Lebong sendiri tidak ada sanksi apapun baik dari forum adat ataupun forum masyarakat yang lain. Meski demikian adanya namun dalam ketentuan undang-undang telah jelas menyatakan baik undang-undang No. 23 tahun 2002 tentang Perlindungan Anak atau undang-undang No. 4 Tahun 1979 tentang Kesejahteraan Anak.

Undang-undang tersebut telah memuat sanksi bagi orang tua terbukti melalaikan tanggung jawabnya, yang mengakibatkan timbulnya hambatan dalam pertumbuhan dan perkembangan anak, maka dapat dicabut kuasa asuhnya sebagai orang tua terhadap anak (pasal 10 ayat 1). Jika hal ini terjadi, maka ditunjuk orang atau badan sebagai wali.

\section{Implikasi tidak terpenuhinya hak-hak anak pasca perceraian orang tua terhadap kehidupan anak di Kabupaten Rejang Lebong}

Satu hal yang paling prinsip dalam membesarkan anak adalah kasih sayang untuk anak; kasih sayang yang tanpa syarat dan tidak ada akhirnya. Jika menginginkan suatu masyarakat yang hidup, sehat, kuat, dan cerdas, orang tua secara khusus harus membuka diri kepada anak-anak dan memberikan kasih sayang yang tulus kepada mereka. Terpenting juga harus memahami psikologi anak dan memahami mereka, sehingga bisa membantu mereka berkembang menjadi seorang yang produktif (Arya, 2008). Untuk dapat menumbuhkan kebahagiaan dalam keluarga, hubungan antara orang tua dengan anak haruslah berdasarkan cinta dan saling percaya.

Psikolog terkenal Gardner berdasarkan penelitiannya yang komprehensif, berpendapat bahwa anak-anak yang tidak mendapat banyak cinta dari orang tuanya menjadi tidak responsif dalam perilaku mereka. Umum ditemui dalam penelitian, bahwa anak-anak tetap melakukan kebiasaan ataupun perangai buruk mereka, bahkan 
walaupun mereka menyadari sepenuhnya akibat-akibat buruk yang dapat timbul dari sana. Katakanlah karena kurangnya perhatian orang tua. Sikap mencari-mencari perhatian semakin menjadi ketika pengawasan dari orang tua kurang atau tidak ketat.

Bahkan, banyak anak yang sengaja melakukan kesalahan hanya untuk menarik perhatian orang tua mereka. Pada akhirnya, orang tua pun terpaksa mengalihkan perhatian kepada mereka. Anak-anak dengan perilaku yang biasa-biasa saja cenderung diabaikan di dalam keluarga. Akan tetapi, anak seperti ini akan menuntut banyak perhatian dan kepedulian ketika mereka menjadi tidak terkontrol. Karena itu, para psikolog menduga bahwa anak-anak bisa menimbulkan banyak masalah agar bisa diperhatikan. Beberapa perilaku khusus bahkan dikategorikan sebagai perilaku patologis.

Benih-benih penyimpangan yang muncul pada diri anak bervariasi keberadaannya. Setidaknya sikap-sikap kebiasaan anak yang disebutkan di atas terjadi di juga Desa Bonder, anak-anak tidak mendapatkan perhatian khusus orang tua. Apalagi yang menyangkut tidak terpenuhinya hak-hak anak pasca pasca perceraian. Dalam hal ini yang terjadi ada sedikit kecenderungan anak yang kesehariannya nakal tidak terkontrol oleh orang tua, hal tersebut dilakukan untuk mendapatkan perhatian dari orang tua dengan memberikan segala kebutuhan yang diinginkan. Terjadinya perceraian di Kabupaten Rejang Lebong selama ini memang acapkali menimbulkan ekses-ekses atau implikasi terhadap kehidupan anak.

Gejala-gejala yang muncul pada diri anak ketika para orang tua baik ayah atau ibu meninggalkan anaknya dengan catatan tidak memenuhi hak-hak anaknya, kehidupan anak berubah drastis. Anak menjadi minder, kurang bergaul atau sulit berinteraksi dengan lingkungan karena ada rasa malu dengankeadaan dirinya, konflik bathin, prestasi yang dimiliki anak juga ada pengaruhnyayaitu menurun yang sebelum aktif di dalam belajar baik formal maupun non formal, nakaltidak terkontrol bahkan pergaulannya bebas. Disadari atau tidak bahwa sesungguhnya ada yang dilupakan oleh para orang tua bahwa faktor keharmonisan juga memiliki pengaruh terhadap kecerdasan anak seperti contoh implikasi terhadap kehidupan anak jika tidak 
diperhatikan segala hak-haknya. Keharmonisan keluarga sangat erat kaitannya dengan perkembangan kecerdasan anak (Azzet, 2010).

Bila anak tumbuh dan berkembang dalam sebuah keluarga yang harmonis kecerdasannya pun dapat berkembang dengan baik pula. Namun, bila anak dibesarkan dalam keluarga yang tidak harmonis, biasanya akan mengalami masalah dalam perkembangan kecerdasaanya. Seperti halnya yang terjadi di Kabupaten Rejang Lebong selama ini. Keluarga yang harmonis tidak harus berasal dari keluarga kaya yang rumahnya bagus, mempunyai mobil mewah, dan pekerjaan yang gajinya besar. Keluarga yang harmonis dibangun berdasarkan hubungan antar anggota keluarga yang rukun, saling menyayangi, menghormati, dan membutuhkan. Itulah sendi-sendi utama dalam keluarga yang harus ada.

Keluarga yang demikian bisa menjalin komunikasi antar anggota keluarga dengan baik, hangat, dan akrab. Komunikasi yang baik adalah komunikasi yang seimbang atau tidak didominasi oleh satu pihak. Oleh orang tuanya dan ada saatnya orang tua mesti bisa mendengarkan apa yang disampaikan oleh sang anak.

Anak-anak yang dibesarkan dalam keluarga yang harmonis akan mempunyai ketenangan dan kegembiraan. Dua hal ini sangat penting perannya dalam menciptakan suasana agar proses belajar sang anak dapat berjalan dengan baik. Anakanak yang intinya merasa tenang karena di dalam keluarganya tidak mudah dalam berpikir dan memahami sesuatu. Selain itu juga bentuk-bentuk pekerjaan terburuk untuk anak adalah ekploitasi baik dari sisi ekonomi maupun seksual komersial anak. Pola eksploitasi anak yang terjadi di Indonesia antara lain melalui orang tua sendiri dengan alasan untuk membantu orang tua sebagai pencari nafkah keluarga. Dalam konteks ini dilatari oleh keluarga miskin, banyak anak, pendidikan anak maupun orang tua rendah, sehingga moral bukan lagi masalah yang harus diperhatikan.

\section{F. Kesimpulan}

Penelitian yang telah dilakukan berkaitan dengan Pemenuhan Hak Anak Pasca Perceraian Orang Tua di Kabupaten Rejang Lebong dan mengamati fakta yang terjadi pada focus penelitian ini, maka kesimpulannya bahwa : 1) hak nafkah anak pasca 
perceraian semua anak hasil perkawinan yang sah ikut ibunya dan di mana dalam pemenuhan hak-hak nafkah anak hanya bersifat pemenuhan yang sementara tidak sepenuhnya bahkan ada juga yang tidak memenuhinya. Dalam hal ini yang banyak berperan pasca perceraian adalah seorang ibu yang bekerja untuk memenuhi kebutuhan anak-anaknya Terlepas dari itu seharusnya ayah yang menanggung hak nafkah anak yang sudah di tetapkan oleh Hakim Pengadilan Agama. 2) tanggung awab orang tua bukan hanya memperhatikan tumbuh kembang anak saja tetapi juga dalam kesehatan fisik anak itu sendiri. 3) kewajiban dan tanggung jawab orang tua terhadap anak yang sudah bercerai memiliki tanggung jawab untuk pengaturan kewajiban terhadap anak pasca perceraian. Mulai dari pengaturan hak asuh anak, nafkah anak sehingga tidak muncul masalah setelah terjadinya perceraian antara orang tua.

\section{Daftar Pustaka}

Ali, D. Muhammad. 2011. Konsep Keluarga Sakinah Perspektif UU No. 1 Tahun 1974 dan PP No.10 Tahun 1983, Yogyakarta: UII Press.

Anshary, M.H. 2014. Kedudukan Hak Anak dalam Perspektif Hukum Islam dan Hukum Nasional, Bandung: CV. Mandar Maju.

Anshori, G. Abdul. 2011. Hukum Perkawinan Islam (Perspektif Fikih dan Hukum Positif), Yogyakarta: UII Press,

Busar, M. 2008. Pokok-pokok Hukum Adat, Jakarta: Paradnya Paramita.

Damang. 2014. Aplikasi Psikologi Hukum Putusan Hak Anak. Dalam http://www.aplikasi-psikologihukum-dalam-putusan.html.

Djojodiguno. 2013. Asas-Asas Hukum Adat, Jakarta: Gunung Adat, 1995. Djamil, Nasir. M, Anak Bukan Untuk Dihukum, Jakarta Timur: Sinar Grafika.

Duriyati, A. S. 2009. Pelaksanaan Putusan Perceraian atas Nafkah Istri dan Anak dalam Praktek di Pengadilan Agama Semarang (Doctoral dissertation, Program Pascasarjana Universitas Diponegoro).

Ekaningsih, L. A. F., 2019. Pola Resistensi Perempuan terhadap Dominasi Suami (Studi Kasus Gugat Cerai Perempuan PNS di Kabupaten Banyuwangi. Jurnal Islam Indonesia. Vol. 6 No. 02 (2016)

Hadikusuma, H. Hilman. 2007. Hukum Perkawinan Indonesia. Bandung: Mandar Maju.

Hadikusumo. 2008. Perceraian data dan fakta. http://www.mtkduo-jika-harusberceraisiapsiap-hadapi-masalahini.

htm/detil/detil.php?id=219\&tipe=kolom . 
Hasan Djuhaendah. 2008. Hukum Keluarga Setelah berlakunya UU No. 1 Tahun 1974 (menuju ke Hukum Keluarga Nasional), Bandung: Penerbit Armico.

Hifni, M. 2017. Hak Asuh Anak Pasca Perceraian Suami Istri dalam Perspektif Hukum Islam. Bil Dalil, 1(02), 49-80.

Kurnia, S. Titon. 2009. Pengantar Sistem Hukum Indonesia, Bandung: PT. Alumni.

Mansari, M., \& Maulana, R. 2018. Kepastian Hukum Terhadap Pengasuhan Anak Mumayiz Pasca Perceraian. Jurnal Yudisial, 11(1), 55-74.

Muhammad, K. Abdul. 2000. Hukum Perdata Indonesia, Bandung: Citra Aditya Bakti.

Murfi, A., Fathurrochman, I., Atika, A., \& Jannana, N. S. (2020). Kepemimpinan Sekolah dalam Situasi Krisis Covid-19 di Indonesia. MANAGERIA: Jurnal Manajemen Pendidikan Islam, 5(1), 119-136.

Riyawadi, Susilo. dkk. 2005. Kamus Besar Bahasa Indonesia, Surabaya: Sinar Terang.

Rozak, A., Fathurrochman, I., \& Ristianti, D. H. (2018). Analisis Pelaksanaan Bimbingan Belajar dalam Mengatasi Kesulitan Belajar Siswa. JOEAI (Journal of Education and Instruction), 1(1), 10-20.

Soekanto, S. 2010. Pengantar Penelitian Hukum, Jakarta: Universitas Indonesia.

Soemiyati. 2009. Hukum Perkawinan Islam dan Undang-Undang Perkawinan (UU No. 1Tahun 1974 tentang Perkawinan). Yogyakarta: Liberty.

Soimin, Soedharyo. 1992. Hukum Orang dan Keluarga. Jakarta: Sinar Grafika, Subekti. 2015. Pokok-Pokok Hukum Perdata, Jakarta: PT. Internusa.

Subekti, R. 2015. Kitab Undang-Undang Hukum Perdata, Jakarta: Pradnya Paramita. Sucia, A. T. 2017. Kedudukan Hak Asuh Anak Pasca Terjadinya Perceraian Karena Salah Satu Orang Tuanya Murtad Menurut Hukum Positif Dan Hukum Islam. Studi Perbandingan Pengadilan Negeri Dan Pengadilan Agama Di Makassar.

Sugiyono. 2009. Metode Penelitian Kualitatif. Kuantitatif dan R\&D, Bandung: Alfa Beta.

Susilo, Budi. 2008. Prosedur Gugatan Cerai. Yogyakarta: Pustaka Yustisia.

Syaifuddin, M. Dkk., 2012. Hukum Perceraian, Palembang: Sinar Grafika.

Syukrie, S. Erna. 2005. Pelaksanaan Konvensi Hak-hak anak ditinjau dari Aspek Hukum, Bogor: Unicef dan Kantor Menko Kesra.

Tanuwidjaja, H. (2011). Hukum Waris Menurut BW, Surabaya: Refika Aditama.

Undang-Undang No. 1 Tahun 1974 tentang Perkawinan Undang-Undang Dasar Republik Indonesia 1945.

Undang-Undang No. 23 Tahun 2002 tentang Perlindungan Anak.

Undang-Undang No. 39 Tahun 1999 tentang Hak Asasi Manusia

Wahyudi, Setya. 2011. Implementasi Ide Diversi dalam Pembaharuan Sistem Peradilan Pidana Anak di Indonesia, Yogyakarta: Genta Publishing.

Waluyo, Bambang. 2018. Penelitian Hukum dalam Praktek, Jakarta, Sinar Grafika..

Yuliana, I. 2017. Tinjauan kompilasi hukum islam dan undang-undang perlindungan anak terhadap nafkah anak akibat perceraian di desa munggung kecamatan pulung kabupaten ponorogo (Doctoral dissertation, IAIN Ponorogo). 